\title{
The effects of laws and regulations on the implementation of food safety practices through supply chain integration and dynamic supply chain capabilities
}

\author{
Binh An Nguyen ${ }^{a^{*}}$
}

${ }^{a}$ Faculty of law, Binh Duong University, Viet nam

\begin{tabular}{l}
\hline A B S T R A C T \\
\hline Article history: \\
Received June 18,2021 \\
Received in revised format July \\
20,2021 \\
Accepted October 22021 \\
Available online \\
October 32021 \\
\hline Keywords: \\
Food Safety Law \\
Supply chain integration \\
Dynamic supply chain capability \\
Food safety \\
Vietnam
\end{tabular}

The objective of the article is to evaluate the role of laws and regulations on food safety in the implementation of food safety laws in Vietnam. Food safety regulations through business orientation, supply chain dynamic capabilities, and supply chain integration aim to ensure food safety and improve firm performance in Vietnam. Research data analysis is based on 389 food firms and the data are analyzed through Smart PLS 3.3.0 software. The results show the important role of food safety law in the implementation of food safety assurance of food enterprises. At the same time, supply chain dynamics and supply chain integration are also factors that have a statistically significant positive impact on the food safety performance of food enterprises in Vietnam.

\section{Introduction}

Food is the main source of human life. However, it can also be a germ that endangers human health and life. Therefore, food safety has become an issue that is not unfamiliar to each person in society. Every day, on the mass media, the situation of food insecurity is reflected, such as "dead mice in hot pot", "Animal feed has carcinogenic substances", causing fear for the whole world society. The issue of food safety is a very urgent and topical issue, especially in the current period. It takes place not only in developing and underdeveloped countries, but also in developed, scientifically advanced countries. Ensuring food safety is one of the most important tasks that state agencies always pay special attention to, considering this is an issue of great significance in terms of economy, social safety, and environmental protection people's health and especially the integration process of Vietnam. However, at present, the loss of food safety is becoming a big problem causing frustration for the whole society. More and more foods produced and processed domestically and abroad of unknown origin are imported into Vietnam. Collective poisoning occurs continuously. The use of additives in production has become widespread. The situation of producing fake food, not ensuring quality and not following the ingredients and technological processes registered with the management agency. Untrue branding and advertising still happen. In addition, the improper use of plant protection chemicals causes water pollution as well as the consequences of residues of these chemicals in food. Not only that, this problem also seriously affects the general economic situation, trade, tourism as well as society. Poor quality of life leads to a serious decline in the quality of the population and race. Therefore, to minimize and prevent the above situation, it is necessary to have the cooperation of everyone, but the most effective tool is to use the law. Currently, the legal system on food safety has become increasingly necessary. The Food Safety Law (2010) has introduced regulations on food hygiene and safety. Those regulations are for businesses and enterprises specializing in food production. In addition, in the regulations, there are fines for enterprises and companies that violate the food safety law. 
Although the Food Safety Law (2010) has been enforced for a long time. However, according to statistics of the Food Safety Department (2019), in Vietnam, there are nearly 90,000 establishments producing, processing, trading food and catering services. From 2012 to March 2019, functional agencies inspected, examined and detected 94,768/224,791 times of establishments (accounting for 42.1\%) that did not meet food safety standards; food sample test results have 2,109/12,785 samples (accounting for 16.4\%) that do not meet hygiene standards. In the period from 2012 to March 2017 nationwide, 2,213 cases of food poisoning occurred at the collective kitchen with 7,653 victims; 297 cases of food poisoning in industrial parks and export processing zones with 4,498 victims; 118 cases of food poisoning in schools with 1,090 students; 238 cases of food poisoning caused by street food with 4,980 victims. Through inspection, the authorities have handled 9,768 cases of food safety violations; destroyed over 180 tons of food that did not ensure food safety. Food poisoning tends to increase and has a significant impact on public health. Food production and trading is still basically small and household-scale, so it is very difficult to control food safety. resources and funding investment, have not met the requirements of reality. Stemming from the current situation of violating the law in the field of food safety, it is required to improve the quality and efficiency of the management of this field to ensure the quality of life and social security. One of the issues that need to be focused on investment is the regulation of the law to manage food safety.

Food safety and hygiene is an important and vital issue for people's health and the nation's development in general (Law on Food Safety, 2010). However, the implementation of food safety and hygiene in most parts of the population, from producers to traders of food products and consumers, is still very low. One of the reasons leading to the current state of food safety violations stems from the inadequacy of legal documents in this field. The situation that a food product is under the management and supervision of 3-4 different ministries and branches at the same time leads to an overlapping situation that is difficult to handle and assign responsibility. Although there are many documents, they overlap, do not clearly define management responsibilities among ministries and branches, and still do not cover all fields, and there are gaps between stages in related management responsibilities. Some new areas have arisen such as functional foods, some toxins and micronutrients have not been given specific and detailed management guidelines, so it is difficult to implement.

The objective of the article is to assess the impact of regulations, laws and policies on food hygiene and safety through supply chain integration and supply chain dynamics. The main content of the article, in addition to the introduction, includes literature review, research methods, research results and conclusions.

\section{Literature review}

\subsection{Food Safety Regulation}

The concept of food safety is no longer strange to every citizen, but not everyone fully understands this concept and its importance to human health and economic development - the society of a country. Food hygiene and safety or food safety in a narrow sense is a science used to describe the handling, processing, preservation, and storage of food by methods of prevention and control of diseases caused by food. Food hygiene and safety also includes several habits and operations in the processing stage that needs to be taken to avoid serious potential health risks. In a broad sense, food hygiene and safety are all issues that need to be handled related to ensuring food hygiene to ensure the health of consumers. A complete food product must be made through many different stages, associated with different subjects. Because of the importance of ensuring food hygiene and safety, issues related to this field must be regulated by legal regulations and this is the basis for the formation of legislation on food safety and hygiene.

Law on food safety and hygiene is a system of generally mandatory rules of conduct set by the state and guaranteed to be implemented to regulate social relations arising in the field of food hygiene and safety. Law enforcement in the field of food safety and hygiene is a process of activities with the purpose of making the provisions of the law on food safety and hygiene come into life, becoming actual legal acts of the food industry, individuals, agencies, and organizations. The Law on Food Safety (2010) defines the object of enforcement of the food safety law as the social relations arising in the process of producing, trading, distributing, and using food. The Food Safety Law (2010) targets individuals and organizations that produce, trade, and consume food. The Food Safety Law (2010) is a system of codes of conduct issued by the Vietnamese government to regulate the production, business, and use of food by individuals and organizations with the aim of ensuring clean food be safe, not cause harm to human's health and life.

\subsection{Institutional press}

The literature distinguishes institutional pressures at three levels (DiMaggio \& Powell 1983): coercive, normative, and mimetic pressures. Coercive pressure has arisen from the presence of strict government rules and regulations and the organization's attempt to comply with established regulatory demands (Wu et al., 2013). Powerful trading partners (e.g., retailers) can also exert coercive pressure on other supply chain actors (e.g., manufacturers) to enforce compliance with specific (e.g., food safety) requirements (Hattersley et al., 2013). Normative pressure is exerted by professional networks or (trade) associations as organizations try to establish legitimacy within their professional associations (Bhakoo \& Choi, 2013); also, it may arise from social obligations as organizations attempt to do the right thing for societies (March \& Olsen, 1983). Mimetic pressure successfully relates to concerns in the market as they try to emulate other organizations that they believe 
(John et al., 2001). In practice, coercive, normative, and mimetic pressures are interdependent; thus, a single practice can prompt the three pressures at a time (DiMaggio \& Powell 1983). Consumers' demand for food safety may not only direct suppliers but also other upstream actors in the food supply chain (Wever et al., 2012; Stranieri et al., 2017). Food supply chains face multiple transaction risks (Trienekens \& Wognum 2013). In the context of the study, food manufacturers are exposed to both supply- and demand-side risks. For example, supply-side risks associated with the sourcing of raw materials can expose the manufacturer to demand-side risks, such as product recalls, negative media image, and reduced market competition. Firms may seek a governance regime that can both optimize transaction risks and enhance competition in the supply chain (Trienekens \& Wognum 2013; Wever et al., 2012). Manufacturers may respond to supply- and demand-side food safety risks by transforming their supply management from arm's length (transactional) to long-term relationships (Tan et al., 2017). Also, firms can be exposed to food safety risks related to their production processes. They may respond to such risks by implementing robust food safety standards and procedures (Wever et al., 2012; Stranieri et al., 2017; Trienekens et al., 2012). Recent studies have documented a positive relationship between institutional pressures and sustainable supply chain practices such as green initiatives (Zhu \& Sarkis 2007), halal standards (Tan et al., 2017; Kurth \& Glasbergen 2017), and corporate social responsibility. The food industry is one of the highly regulated sectors; firms must respond to such legislative demands by implementing various food safety practices.

\subsection{Supply chain integration}

Supply chain integration is a function of long-term relationships, strategic information sharing, information technology (IT) connectivity and logistics integration. Some studies have applied the concept of information integration to the use of information technology or the practice of sharing information between trading partners (Jacobs et al., 2016). Prajogo and Olhager (2012) argue that both the technological and social aspects of information integration are essential for the supply chain integration. Technologically, the internet, electronic data interchange, and advanced IT systems can provide interactive ways to coordinate activities and manage supply chain relationships. food application (Kittipanya-Ngam \& Tan 2020). IT systems such as warehouse management systems (for quality and safety control during storage and distribution), laboratory information management systems (for product or animal control) and enterprise resource planning systems (for collaborative forecasting and planning programs) are critical to food supply chain transparency and integration (Trienekens et al., 2012). IT connectivity allows supply chain actors to manage complex information exchanges in real time (see Prajogo \& Olhager 2012; Kittipanya-Ngam \& Tan 2020). Studies such as Vanpoucke et al. (2017), using global production data, and Zhang et al. (2016), based on evidence on Chinese manufacturing conglomerates, showed a direct (positive) IT connection for supply integration.

Integrated logistics aims to provide a seamless connection between ingredients from supplier to processor (Prajogo \& Olhager, 2012). However, there is still a lack of consensus on the relationship between logistics integration and supply chain performance. According to Prajogo et al. (2016), integration and logistics are indirectly related through other activities such as lean manufacturing processes (e.g., total quality control principles). In the food supply chain, integrated logistics involves managing microbial growth and food waste as the raw (or primary) product moves from supplier to producer. This is necessary but not scientific to ensure the quality and safety of the carcass product. In this study, food safety was the performance indicator, which may also depend on intermediate processes such as performance.

The present study builds on Prajogo and Olhager (2012), who conceptualize supply chain integration as a function of longterm relationships, strategic information sharing, information technology connection, and logistics integration.

The Transaction Costs Economics (TCE) framework (Williamson, 1991) provides three generic forms to govern supply chain relationships; they include market, hybrid, and hierarchical, which may vary in terms of incentives, uncertainty reduction, and transaction costs. In a market type of governance, price is the sole mechanism to coordinate transactions, often, between anonymous parties, and such relationships are short-term. The other extreme is a hierarchical form of governance where all the production, distribution, and marketing activities are under the control of one entity. The hybrid form of governance lies between the classical market and hierarchy forms of governance (Williamson 1991). According to TCE, the behavior of the trading partners (e.g., opportunism) and the nature of transactions (e.g., uncertainty and specificity of investments to safeguard food safety) may provide useful information to determine the type of governance regime that is needed to instill order in the relationships. The hybrid form of governance has different forms, including long-term relationships, strategic alliances, and joint ventures (Zhang \& Aramyan, 2009). According to Menard and Valceschini (2005), the hybrid form is more common and attractive than the other two regimes to govern complex relationships of food supply chains. They argue that the hybrid form allows supply chain actors to keep property and decision rights distinct while providing each actor the flexibility to select reliable partners for joint planning and investments (in key supply chain resources such as information technology and logistics) and employ strategic information exchanges with other actors in the chain. Prior studies (e.g., Chen \& Paulraj, 2004; Prajogo \& Olhager 2012) found a positive correlation between long term relationships and information and logistics integration. In this era of complex and rapidly evolving food supply chains, long-term partnerships can be paramount to deal with food safety hazards (Trienekens \& Zuurbier 2008; Trienekens et al., 2012). The present study extends the work of Prajogo and Olhager (2012) by testing this relationship in the context of the food industry, which is under increasing pressure and scrutiny to ensure food safety. Also, in the present study, long-term relationships are conceptualized as an organizational response to food safety risks and the basis for information and logistics integration. 
Several studies have applied the notion of information integration to refer to either the use of information technologies or information sharing practices between trading partners (Jacobs et al., 2016). Prajogo and Olhager (2012) argue that both the technological and social aspects of information integration are necessary for supply chain integration. On the technological side, the internet, electronic data interchange, and advanced information technology (IT) systems can provide interactive ways to coordinate activities and manage relationships in food supply chains (Kittipanya-Ngam \& Tan, 2020). IT systems such as warehouse management systems (for the control of quality and safety in storage and distribution processes), laboratory information management systems (for the control of products or animals), and enterprise resource planning systems (for collaborative planning and forecasting programs) are crucial for food supply chain transparency and integration (Trienekens et al., 2012). IT connections allow supply chain actors to manage complex information exchanges in real-time (see Prajogo and Olhager 2012; Kittipanya-Ngam \& Tan, 2020). Studies such as Vanpoucke et al. (2017), using global manufacturing data, and Zhang et al., (2016), based on evidence of Chinese manufacturing firms, have shown a direct (positive) effect of IT connection on supply integration.

Logistics integration aims to provide a seamless connection for the flow of materials from suppliers to processors (Prajogo \& Olhager, 2012). There is, however, a lack of consensus regarding the relationship between logistic integration and supply chain performance. According to Prajogo et al. (2016), logistics integration and performance are indirectly related via other operations such as lean production processes (e.g., total quality control principles). In the food supply chain, logistics integration involves the management of microbial growth and food waste as raw materials (or primary) products move from suppliers to manufacturers. This is necessary but not sufficient to ensure the quality and safety of the final product. In the present study, food safety is the performance indicator, which may also depend on intermediate processes such as the implementation of prerequisite programs, critical controlling and monitoring points, and compliance procedures (Luning et al., 2011). Logistics integration can influence the intensity of food safety practices and thereby food safety output.

\subsection{Supply chain dynamic capability}

An influential paper by Lee (2004) argued that successful companies are those that have agile supply chains that can rapidly respond to short-term demand changes and adaptable supply chains that can be reconfigured to address long-term marketplace alterations. Agility is characterized by flexibility and responsiveness and spans organizational structures, processes and managerial mindsets (Blome et al., 2013; Christopher \& Towill, 2000). SAG, therefore, extends beyond firm boundaries and requires alignment with customers and suppliers (Blome et al., 2013; Braunscheidel \& Suresh, 2009). Swafford et al. (2006) suggest agility is a supply chain level capability because it allows buyers and suppliers to seize opportunities once they are sensed (Swafford et al., 2006). Other scholars argue that SAG is a fundamental capability needed to endure and flourish in volatile environments (Braunscheidel \& Suresh, 2009; Gligor \& Holcomb, 2012). Blome et al. (2013) suggest that SAG is a dynamic capability that can positively influence the operational performance of the firm. SAD has a longer-term orientation and refers to the ability of supply chain partners to reconfigure and transform supply chain design to match anticipated market changes (Ketchen \& Hult, 2007; Lee, 2004). Dubey et al. (2018) argue that SAD prepares supply chain members to adjust according to the market situation and gain a desired competitive advantage. When agility and adaptability capabilities become integrated between supply chain partners, a complex adaptive system forms (Choi et al., 2001), which can seize new opportunities in the short term and transform supply chain infrastructure in the longer term to address changes in consumer demand (Whitten et al., 2012). As SAG and adaptability capabilities result from the firm's ability to reconfigure firm-level and supply chain-level resources, they can be positioned as dynamic, supply chain-level capabilities (Blome et al., 2013; Eckstein et al., 2015; Whitten et al., 2012). Yet, supply chain partners cannot seize marketplace opportunities if these opportunities are not sensed in the first place. Day (1994) argues that market-driven firms are distinguished by an ability to sense events and trends in their markets ahead of the competition. These firms can anticipate more accurately the responses to actions designed to retain or attract customers, improve channel relations, or outmaneuver the competition (Day, 1994). Market sensing is considered a capability because managers can sense new opportunities by following a sequence of information processing activities used to stimulate organizational learning (Day, 1994; Fiol \& Lyles, 1985). The learning process involves gathering new information about trends, events, opportunities, and threats in the market environment, absorbing that knowledge into the firm and then reconfiguring knowledge resources considering the new information (Day, 1994; Fiol \& Lyles, 1985). To sense new opportunities, managers undertake horizon scanning activities, which involve reviewing trade magazines, attending conferences, and speaking with suppliers and customers to identify new trends and technological breakthroughs (Cousins et al., 2011). Integrating suppliers in horizon scanning increase the activity's breadth and depth, helping the firm to identify promising innovations and allowing new information to be absorbed (Brandon-Jones \& Knoppen, 2018; Cousins et al., 2011). Such market sensing activities allow supply chain partners to develop the structures, technologies and policies needed to respond to market changes in an efficient manner (Ngai et al., 2011). Market sensing becomes a dynamic capability, when the intended use is to affect change within the firm's tangible and intangible assets, such as absorbing novel technological information when developing new products (Bharadwaj and Dong, 2013). Market sensing becomes a dynamic supply chain capability when supply chain partners actively scan the market for new knowledge and innovation and use this information to alter the supply chain's resource base (Aslam et al., 2018; Tse et al., 2016).

Collectively, market sensing, SAG and SAD act as a coherent cluster of DSCCs because they allow supply chain partners to sense new market opportunities, to seize these opportunities in the short term and to transform supply chain resources in the longer-term to match anticipated marketplace changes (Aslam et al., 2018). An emergent body of literature has found a 
positive relationship between the development of DSCCs and firm performance. For example, Ju et al., (2016) found that DSCCs positively influence technological innovation and operational performance. Other authors have found that DSCCs positively influence the sustainability of supply chains (Beske, 2012; Beske et al., 2014; Hong et al., 2018). Beske (2012) found that DSCCs can enhance a firm's sustainability performance through the protection of rare resources and their inimitability by building long-term relationships and trust with supply chain partners. Two years later, Beske et al., (2014) argued that DSCCs improve a firm's environmental and social performance by enhancing the transparency and traceability of supply chain practices. In a somewhat contradictory study, Hong et al. (2018) found that DSCCs positively affect a firm's environmental performance but have no effect on social and economic performance. While this literature has examined performance implications, it has yet to identify the strategic orientations and managerial mindsets that underpin the emergence of DSCCs. We now turn our attention to the EO and supply chain learning literature to gain insights on how these constructs can support the development of DSCCs.

\subsection{Entrepreneurial orientation and dynamic supply chain capabilities}

Teece (2007) suggests that firms with strong dynamic capabilities are intensely entrepreneurial. He argues that the ability of management to identify opportunities for investment in co-specialized assets (i.e., complementary and value enhancing assets) is fundamental to dynamic capabilities (Teece, 2007). In particular, the decision on when and how to invest depends on management's entrepreneurial capacities with respect to matching up and integrating relevant co specialized assets (Teece, 2007). Entrepreneurially oriented managers can match co-specialized assets by absorbing innovative technologies into the firm and matching it to suitable knowledge sets possessed by operational staff (Sahi et al., 2019). EO is a strategic orientation that captures the specifically entrepreneurial aspects of firms' strategies (Covin \& Slevin, 1989; Hakala, 2011; Wiklund \& Shepherd, 2005). The predominant view of what it means to be entrepreneurial is an organizational tendency towards concurrently taking risks, continuously innovating to rejuvenate the firm's market offering and being more proactive than the competition (Gupta et al., 2014; Miller, 1983). Indeed, EO is defined as the "processes, structures and behaviors of the firm that are characterized by innovativeness, pro-activeness and risk-taking" (Stam \& Elfring, 2008, p. 98). Innovativeness refers to a willingness to introduce newness and novelty through experimentation and creative processes aimed at developing new products and services (Dess \& Lumpkin, 2005). Yet, innovative ideas do not always originate from within firm boundaries but often stem from external sources such as suppliers (Bidault et al., 1998; Powell et al., 1996). Entrepreneurial managers that can extend market scanning activities beyond firm boundaries, to include suppliers, are better able to identify promising innovations and can absorb this information and match it with the knowledge assets of employees (Bharadwaj \& Dong, 2013; Cousins et al., 2011). The foundation for dynamic capabilities is set when a manager combines innovative assets with the knowledge resources of the firm to achieve fit with the changing business environment (Teece et al., 1997). When these innovative ideas stem from suppliers and are matched with the knowledge assets of the firm, the foundation is set for DSCCs to emerge.

\subsection{Implementation of food safety practices}

For decades, supply chain performance has been associated with cost, quality, price, and delivery conditions and applied in the context of non-food industries (Prajogo \& Olhager, 2012). However, the nature of products/production and distribution are significantly different in food supply chains. In the present study, the intensity of food safety practices (i.e., activities necessary to control microbiological safety hazards and assure product safety) is measured (1) by assessing the organizational structures supporting food safety (Luning et al., 2011), administrative conditions and information systems-and implementation of food safety management systems. In the latter, a plethora of Food Safety Management Systems (FSMS) are present to govern food safety in supply chains, including Hazard Analysis Critical Control Point (HACCP), British Retail Consortium (BRC), International Organization for Standardization (ISO) 22,000, Safe Quality Food (SQF), International Food Standard (IFS), and Food Safety System Certification (FSSC) 22,000 (Akkerman et al., 2010). Strong organizational structures supporting food safety (Luning et al., 2011) and the implementation of one or more FSMSs can enhance food safety output (Trienekens et al., 2012).

\section{Research Methods}

\subsection{Context and sample}

The system of legal documents on food safety assurance in Vietnam is relatively comprehensive and rich, and many important regulations have been codified, including areas such as public health and safety, regulations on food safety and hygiene. animal and plant quarantine, the system of regulations on business, export and import of food. In particular, the Law on Food Safety (2010) is the highest legal document that stipulates the management and implementation of the process of ensuring food safety. Along with documents according to the legal system on food safety, many legal documents and ordinances related to food safety control have also been promulgated such as the Law on Technical Standards and Standards, the Law on Product Quality. Commercial Law, Advertising Law, Criminal Law, Veterinary Ordinance, Plant Protection Ordinance, etc. and a series of sub-law documents were also issued. The above documents have created a legal corridor for the work of ensuring food safety, meeting the requirements of international economic integration. A system of food standards has been developed, creating conditions for businesses and state management agencies to apply in the process of food production and 
business as well as food safety control. Food safety legislation in general has made a great step forward in assigning specific responsibilities to each line ministry for food safety management in the market. Based on decentralization to functional forces and departments, creating synergy in ensuring food safety.

To evaluate the role of laws and regulations on food safety (we collectively refer to them as institutional pressure) on the food safety performance of enterprises in the food industry. Besides, responsible business towards the goal of sustainable development is also a factor that promotes food businesses to ensure food quality and safety. By participating in the global supply chain to ensure sustainable development and being oriented for sustainable development, businesses with dynamic capabilities with sharp business strategies will achieve high efficiency in the supply chain globally and thereby driving businesses to practice better food safety.

To achieve the research objective, we conducted direct and online surveys via email to all businesses in the food industry that are members of the Vietnam Food Association, the Ho Chi Minh Food Association. We sent out all 850 votes and got 489 votes. After sorting, reviewing, and discarding, but invalid votes such as too many blanks and abnormal signs, there are 389 valid votes left for analysis.

\subsection{Research models}

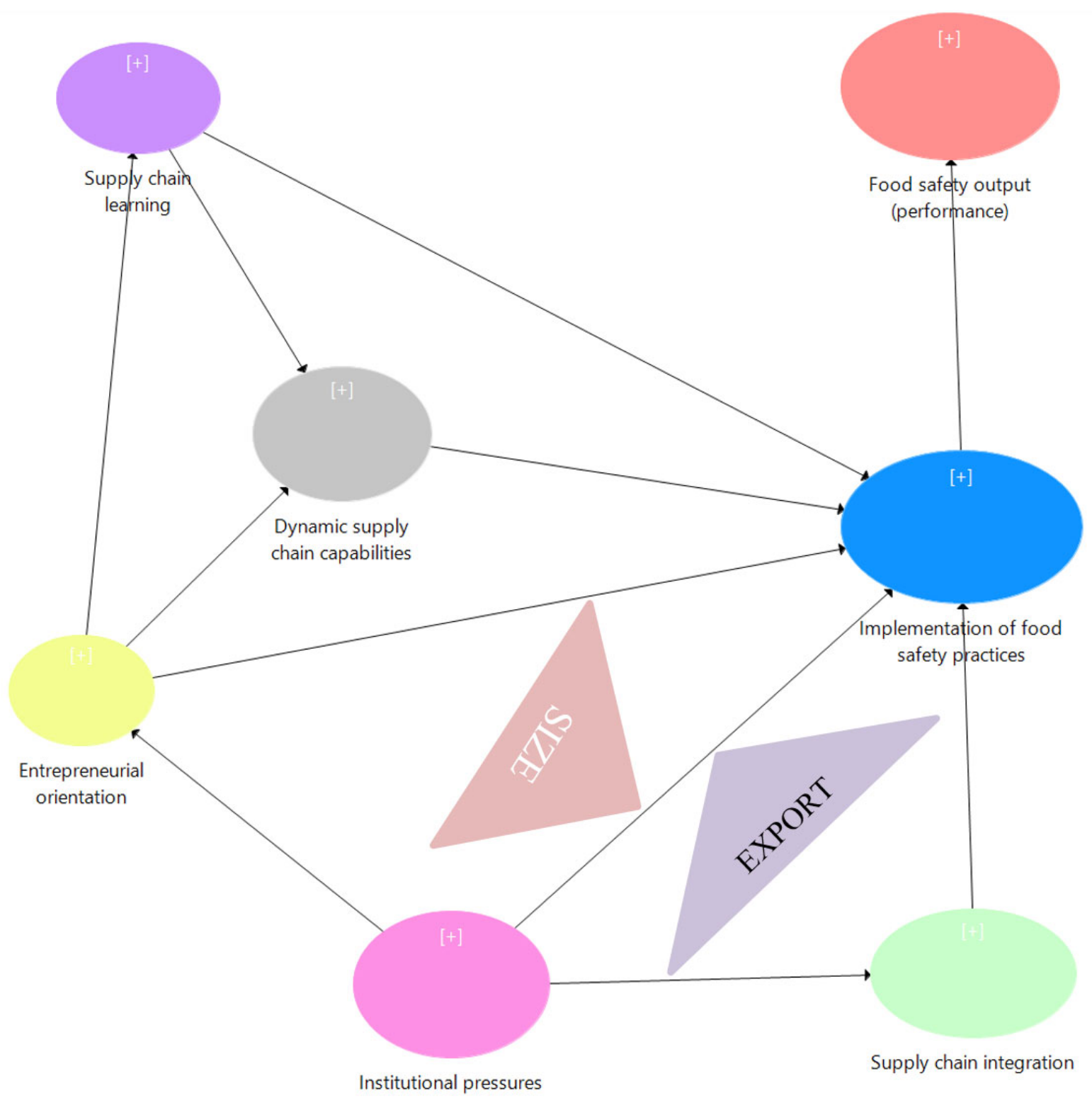

Fig. 1. Research model 
The research model in Fig. 1 is built and developed based on the study of Abebe (2020); Aslam et al., (2020), Prajogo and Olhager (2012). Research to examine the linkage of factors in the supply chain includes suppliers, manufacturers, and customers - supply chain integration; institutional pressure; business orientation and supply chain dynamic capacity of enterprises in the Vietnamese food industry to implement food hygiene and safety and the output of this activity. The concepts in the model are developed based on the studies of Abebe (2020); Aslam et al. (2020) and Prajogo \& Olhager (2012). Our research applies institutional theory, supply chain integration, and supply chain dynamic capabilities.

Dynamic supply chain capabilities: Measured by three development dimensions from Aslam et al., (2018) includes: sensing, seizing and transforming capabilities.

Market capability (MSC) is adopted sensing from Morgan et al., (2009) and consists of five items measured on a scale of 1 (strongly disagree) to 5 (strongly agree).

Supply chain agility (SAG) is based on the study by Blome et al., (two thousand and thirteen). It includes five items measured on a scale of 1 (strongly disagree) to 5 (strongly agree).

Supply chain adaptability (SAD) is based on the SAD construct from Lee's (2004) Triple-A supply chain, including a fiveitem scale developed in the Whitten et al., (2012) study and further validated in Aslam et al., (2018) and Dubey et al., (2018), and is measured on a scale of 1 (strongly disagree) to 5 (strongly agree).

Entrepreneurial orientation (EO)

The EO scale was adopted from the study by Jantunen et al., (2005). All items were measured on a five-point scale, with 1 representing "strongly disagree" and 5 representing "strongly agree".

Food safety output (performance): Includes 7 items developed from research by Abebe (2020) and Luning et al., (2015). Scales are measured using a 5-point Likert scale ranging from 1 being very low to 5 being very high.

The research hypotheses are as follows:

H1: Dynamic supply chain capabilities have a positive impact on Implementation of food safety practices.

$\mathbf{H}_{2}$ : Entrepreneurial orientation has a positive impact on Dynamic supply chain capabilities.

H3: Entrepreneurial orientation has a positive impact on Implementation of food safety practices.

$\mathbf{H}_{4}$ : Entrepreneurial orientation has a positive impact on Supply chain learning.

Hs: Implementation of food safety practices has a positive impact on Performance.

H6: Institutional pressures have a positive effect on Entrepreneurial orientation.

$\mathbf{H}_{7}$ : Institutional pressures have a positive impact on Implementation of food safety practices.

Hs: Institutional pressures have a positive impact on Supply chain integration.

H9: Supply chain integration has a positive impact on Implementation of food safety practices.

$\mathbf{H}_{10}$ : Supply chain learning has a positive impact on Dynamic supply chain capabilities.

H11: Supply chain learning has a positive impact on Implementation of food safety practices.

H12: Export and Size have a moderating role in the relationship between Institutional pressures and Implementation of food safety practices.

\subsection{Analytical techniques}

The data is collected as primary data through survey form. First, the author checks and discards invalid questionnaires. Then, these primary data are imported into Excel for storage, followed by data transfer to SPSS 23.0 software for descriptive statistics and at the same time, SMARTPLS 3.6 software is used to evaluate the scale and confirm determine the importance of the factors as well as test the hypotheses posed.

- Descriptive statistics using SPSS 
+ Descriptive statistics on the characteristics of the research sample (about gender, education level, age, number of years of experience, working position, place of work).

+ Descriptive statistics for observed variables of each factor.

- Check the reliability of the scale: Cronbach's Alpha coefficient $\geq 0.6$, the total variable correlation coefficient $>0.3$ (Hafiz \& Shaari, 2013).

- Exploratory factor analysis (EFA): Using extracted variance to evaluate the scale: The scale is accepted when extracted variance $>50 \%$ and Eigenvalue $>1$ (Hair et al., 2006). Factor loading $\geq 0.5$ (Hair et al., 2006).

- Evaluation of the measurement model: evaluation of the reliability of that scale is done through the PLS algorithm (PLS Algorithms) in SMART PLS, including 3 values: reliability, convergence value and decomposition value. separate.

+ The composite reliability assessment measures the reliability of a set of observed variables measuring a concept (factor) and the reliability coefficient CA measures the intrinsic consistency across the set of important variables. closeness of the answers. The composite confidence is significant when the value is greater than 0.7 and the CA confidence level is 0.6 or higher.

+ Evaluation of the convergent value of the scale: The scale achieves the convergent value when the normalized weights (Outer loading) of the scale are high $(>0.5)$ and statistically significant $\left(P_{-}\right.$value $\left.<0.05\right)\left(P_{-}\right.$value $\left.<0.05\right)$. Henseler et al., 2009) and the total variance extracted reflects the overall variability of the observed variables explained by the latent variable (Henseler et al., 2009) that is significant when the value is above 0.5.

+ Evaluation of discriminant value: According to Henseler et al., (2009), discriminant value is the degree to which a concept of a particular latent variable is distinguished from the concept of other latent variables. There are two ways to evaluate:

- The cross-load factor must have a load-factor weight of the latent variable representative which must have a higher value than the others.

- The conditional region of Fornell and Larcker (1981) compares the square root of the AVE of each concept with the correlation (Pearson) between the concept of latent variable. The square root of AVE should be higher than the correlation of other concepts.

+ Multicollinearity detection: Variance Inflation Factor (VIF) when VIF exceeds 10 (Henseler et al., 2009), it is a sign of multicollinearity.

- Evaluation of the structural model: to test the relationship between concepts, the impact and intensity of the independent variables on the dependent variable through the intermediate variable. The evaluation criteria are as follows:

+ Measure the population coefficient of determination (R-square value), which is an indicator to measure the model fit of data (the ability of the model). Henseler et al., (2009) describe the R-square values of 0.67, 0.33 and 0.19 in the PLS pathway models as strong, moderate and weak, respectively.

+ Path Coefficient (impact weight) of the PLS structural model: the degree of impact of concepts with each other, can be understood as the standard beta coefficient of least squares regression, providing a real confirmation of the hypothesized theoretical relationship between latent variables. This coefficient has the sign $(+)$ for the positive effect, and the sign $(-)$ for the opposite direction.

+ T-value: If the T-value is $>1.96$, the test is statistically significant at $5 \%$ level.

- Bootstrap Estimation Test: The non-parametric Bootstrap (Davison and Hinkley, 2003; Henseler et al., 2009) procedure can be used in the PLS sampling path to provide confidence intervals for all estimators. parameters, building the basis for statistical inference. The Bootstrap template is generated by randomly drawing alternate cases from the original template. PLS estimates the model path for each Bootstrap template. The path model coefficients are formed into a bootstrap distribution that can be viewed as an approximation of the sampling distribution.

\section{Results}

The food industry is an important contributor to Vietnam's economy, which has achieved rapid growth during the past decade thanks to technological improvements and private sector participation. Vietnam has become an important supplier of products: rice, seafood, fresh food, and processed food. The food industry is oriented to serve domestic and export needs, so up to now, Vietnam has become a large-scale business with the participation of more than 7,000 enterprises with nearly one million employees, of which $84 \%$ are small and medium-sized enterprises with less than 50 employees, the average growth 
rate of the food industry in the past 10 years has averaged $10 \%$ and contributed $15 \%$ of the gross domestic product (GDP) to the economy. economy (Ministry of Agriculture and Rural Development, 2017).

As an agricultural country, with abundant natural resources and favorable climatic conditions along with relatively low labor costs have created advantages for Vietnam in the food sector. In addition, the ability to produce, process and develop agricultural and food products of high quality, quantity and large scale meets the needs of consumers around the world. Vietnam has been trying to turn the food industry into a strong industry through efforts in innovation and technology development and application of international standards on food hygiene and safety, establishing a competitive position in the global food industry.

Of the 389 food businesses in the analyzed data, 32\% are processed foods, $13 \%$ are confectionery businesses, $10 \%$ are agricultural products, and $6 \%$ are seasonings - sauces. $9 \%$ of businesses are butter and milk, $16 \%$ are businesses of beverages - soft drinks, the rest are businesses of raw materials for the food industry. In which, enterprises in the North account for $45 \%$, the South $38 \%$, the rest are food enterprises in the Central region of Vietnam.

After performing descriptive statistics, the research tests the validity and reliability of the scales of latent variables in the research model; Perform exploratory factor analysis (EFA) using SPSS 23.0 software. The results show that most of the scales for testing latent variables satisfy the condition of reliability and validity with Cronbach's Alpha coefficients greater than 0.7 and total correlations greater than 0.4. Excluding EO6; MSC5; SAG3 has a total variable correlation of less than 0.3, so it is excluded from the research model.

Next, the study carried out EFA exploratory factor analysis on SPSS 23.0, which resulted in the extraction of 7 factors (first order factor) with the results $\mathrm{KMO}=0.812>0.5(\mathrm{Sig} .=0.000)$ and the value of Eigenvalues stopped at $1,205>1$, the total extracted variance (TVE) was $72,783(\%)>50 \%$. This means that the initial parameters are satisfied to perform further tests and test the research hypotheses.

Next, we analyze the overall reliability of the scale, the results from Smart PLS 3.3.0 software are as follows:

Table 1

Construct Reliability and Validity

\begin{tabular}{lcccc} 
& & & Average Variance Extracted (AVE) \\
\hline Dynamic supply chain capabilities & Cronbach's Alpha & rho_A & Composite Reliability & 0.885 \\
Entrepreneurial orientation & 0.881 & 0.898 & 0.892 & 0.722 \\
Implementation of food safety practices & 0.893 & 0.894 & 0.873 & 0.674 \\
Institutional pressures & 0.875 & 0.877 & 0.910 & 0.633 \\
Performance & 0.912 & 0.916 & 0.920 & 0.718 \\
Supply chain integration & 0.926 & 0.969 & 0.907 & 0.752 \\
Supply chain learning & 0.906 & 0.912 & 0.844 & 0.620 \\
\hline
\end{tabular}

From the results in Table 1, all the research variables satisfy the conditions of reliability. All Cronbach's Alpha coefficients are greater than 0.875 and less than 0.926 , which means that all scales of latent variables have very good reliability coefficients (Hair et al., 2011, 2014, 2017; Hesenler et al., 2009, 2015). All latent variables have AVE coefficients greater than 0.5 according to Hesenler et al. (2015). The fact that the minimum value of AVE is 0.580 and the highest is 0.752 , which means that all the research variables satisfy the initial analysis. Next, we analyze the discriminant validity of the latent variables, the results are as follows:

Table 2

Discriminant Validity (The results of Fornell-Larcker Criterion)

\begin{tabular}{|c|c|c|c|c|c|c|}
\hline 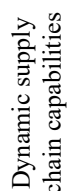 & 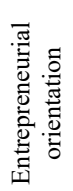 & 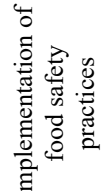 & 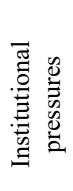 & 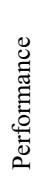 & 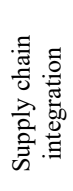 & 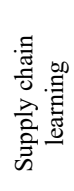 \\
\hline
\end{tabular}

\begin{tabular}{|c|c|c|c|c|c|c|c|}
\hline Dynamic supply chain capabilities & 0.850 & & & & & & \\
\hline Entrepreneurial orientation & 0.586 & 0.821 & & & & & \\
\hline Implementation of food safety practices & 0.420 & 0.307 & 0.796 & & & & \\
\hline Institutional pressures & 0.227 & 0.147 & 0.137 & 0.847 & & & \\
\hline Performance & 0.299 & 0.187 & 0.200 & 0.172 & 0.867 & & \\
\hline Supply chain integration & 0.317 & 0.287 & 0.367 & 0.295 & 0.123 & 0.787 & \\
\hline Supply chain learning & 0.251 & 0.134 & 0.221 & 0.361 & 0.076 & 0.298 & 0.761 \\
\hline
\end{tabular}


The evaluation of convergence value of latent variables is based on the index of external loading coefficient and extracted variance AVE. If the external factor loading of a variable $>0.7$ is considered ideal, a range between 0.4 and 0.7 should be considered before deletion (Henseler et al., 2009). According to Fornell and Larcker (1981), the value of the total variance extracted AVE must be equal to or above 0.5 to be satisfactory, that is, the latent variable can explain more than half of its variance with the mean. If AVE is less than 0.5, that latent factor or variable is usually considered to be removed from the research model. Table 2 analyzes the discriminant validity among latent variables in the research model. The results show that the values outside the diagonal are smaller than the bold values on the diagonal. The largest off-diagonal value of 0.586 is still less than the smallest on-diagonal value of 0.761, which means that as suggested by Hair et al. (2006, 2011, 2014, 2017) and Hesenler et al., $(2009,2015)$ is to satisfy the condition to ensure the discriminant validity of the research variables. Thus, the variables in the research model are satisfied to perform the next analysis.

The R-square results are as follows:

Table 3

The results of R-Square

\begin{tabular}{lcc} 
& R Square & R Square Adjusted \\
\hline Dynamic supply chain capabilities & 0.373 & 0.369 \\
Entrepreneurial orientation & 0.022 & 0.019 \\
Implementation of food safety practices & 0.585 & 0.580 \\
Performance & 0.087 & 0.437 \\
Supply chain integration & 0.018 & 0.084 \\
Supply chain learning & $R^{2}=1-\frac{E S S}{T S S}$
\end{tabular}

Inside:

ESS stands for Residual Sum of Squares, i.e. sum of squared deviations of residuals.

TSS stands for Total Sum of Squares, i.e. the sum of squared deviations of all research factors.

From this formula, $\mathrm{R}^{2}$ will be in the range from 0 to 1 . The closer $\mathrm{R}$ squared is to 1 , the more suitable the built model is to the dataset used for regression. The closer R-squared is to 0 , the less suitable the built model is for the dataset used for regression. In a special case, in a univariate regression equation (only one independent variable), $\mathrm{R}^{2}$ is the square of the correlation coefficient $\mathrm{R}$ between those two variables (Hair et al., 2011). The results of the model show that the R-square coefficient of the Implementation of food safety practices is 0.585 , which means that the variables in the research model explain nearly $60 \%(58.5 \%)$ of the variation of the Implementation of food safety practices. practices that is a very good number (Henseler et al., 2015). The results of the correlation assessment based on the f-square coefficient are as follows:

Table 4

The results of F-Square

\begin{tabular}{|c|c|c|c|c|c|c|}
\hline 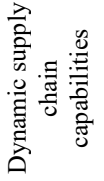 & 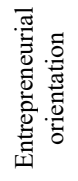 & 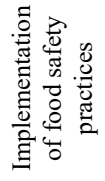 & 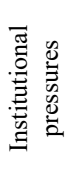 & 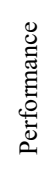 & 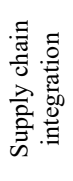 & 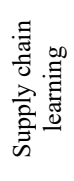 \\
\hline & & 0.397 & & & & \\
\hline \multirow{4}{*}{0.495} & & 0.312 & & & & 0.189 \\
\hline & & & & 0.311 & & \\
\hline & 0.199 & 0.238 & & & 0.362 & \\
\hline & & 0.305 & & & & \\
\hline 0.189 & & 0.322 & & & & \\
\hline
\end{tabular}

$\mathrm{f} 2=\left(\mathrm{R} 2\right.$ _included $-\mathrm{R} 2 \_$excluded $) /\left(1-\mathrm{R} 2 \_\right.$included $)$

where R2_included and R2_excluded are the R squared values of the endogenous variable when the exogenous variable is included or excluded from the model, respectively. That means the value of R 2 is calculated by PLS twice, the first time with the full latent exogenous variable (resulting in R2 included) and the second time with the exogenous variable not in the 
model (giving the value of R2_included). R2_excluded). The values $f$-square including: $0.02,0.15$, and 0.35 , respectively to the small, medium and large impact values (Hair et al., 2006, 2011, 2014, 2017; Henseler et al., 2009, 2015) of exogenous variables. If the effect size is $<0.02$ then it is considered as having no effect.

Table 5

Model fit

\begin{tabular}{lll}
\hline & Saturated Model & Estimated Model \\
\hline SRMR & 0.048 & 0.050 \\
d_ULS & 0.693 & 0.689 \\
d_G & 0.579 & 0.680 \\
Chi-Square & 6985.025 & 7124.732 \\
NFI & 0.895 & 0.899 \\
\hline
\end{tabular}

The fit of the model is determined by the correspondence between the observed covariance matrix and an estimated covariance matrix derived from the proposed model. SEM uses a series of measures to describe how the research hypothesis explains the input data. The input data forms a matrix of covariance between the measured variables. Some of the metrics are as follows:

SRMR: standardized root mean square residual: is the difference between the actual data part and the predicted model part. Ranging from 0 to 1 , the smaller the better, $\mathrm{SRMR}=0$, the predictive model completely matches the data, $<=5 \%$ is good.

CFI: comparative fix index. Get the fit of a model to a set of data and compare it with the fit of another model to the data itself. Ranging from 0 to 1 , the bigger the better. CFI $>=90 \%$. CFI is a modified version of RNI. CFI is used to avoid underestimation of fit when the sample size is small when using NFI. Because of sample size, in this study, we use NFI.

From the analysis results, it is shown that the research data is completely consistent with the research model. Therefore, the study is eligible to test the research hypotheses:

The results of testing the research hypotheses are as follows:

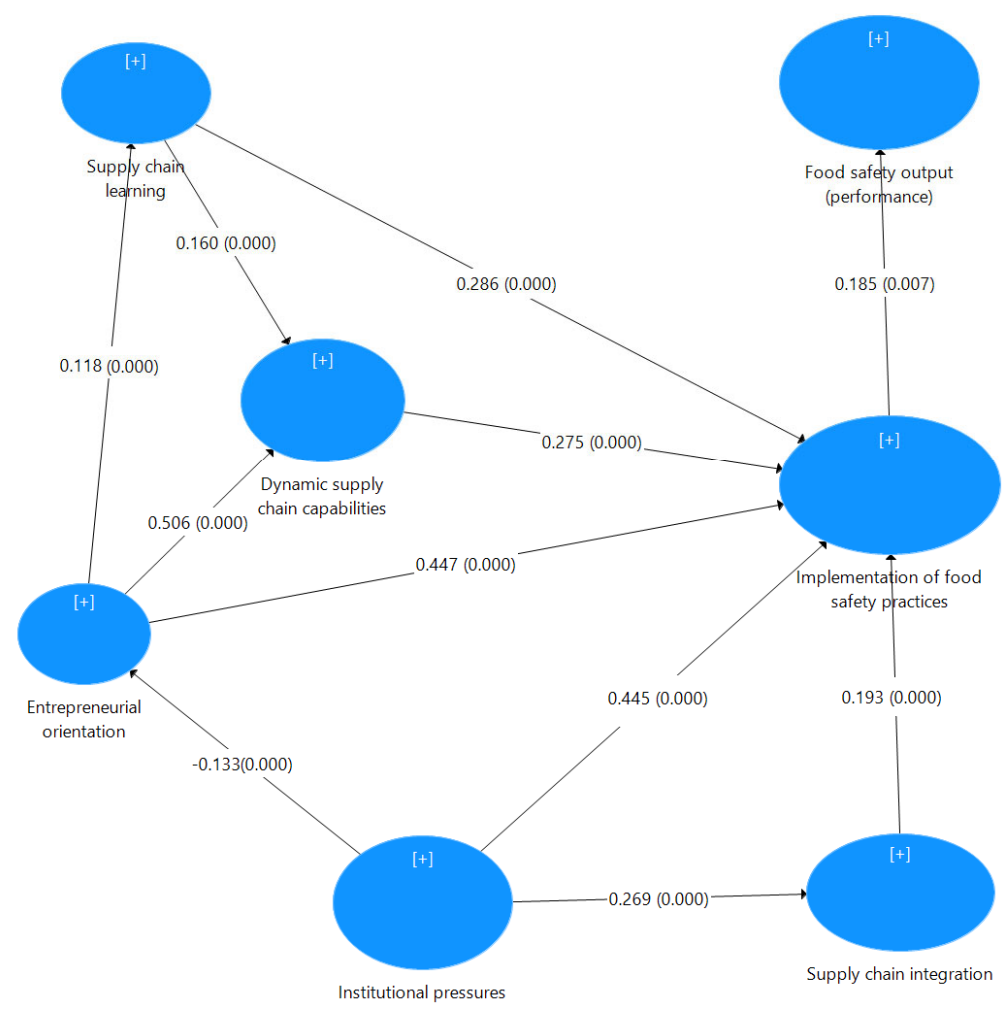

Fig. 2. The results of bootstrapping results

From the results shown in Fig. 2, all hypotheses are specifically supported as follows: 
The results show that Institutional pressures have a very strong positive impact on Implementation of food safety practices with a very strong impact coefficient of 0.445 at the $1 \%$ significance level $\left(\mathrm{P}_{\text {_value }}=0.000\right)$. For food businesses in Vietnam, the initiative to ensure food hygiene and safety is not high. Enterprises have not yet ensured food safety, but mainly when the state has laws and regulations to apply and regularly check, new businesses implement food hygiene and safety. Therefore, in the food industry, the role of institutional pressure (laws, regulations of the state) is extremely important. In the qualitative interview results of the study, businesses said that they evade implementation of food safety activities in order to compete on product prices. Therefore, there are many cases of poisoning in industrial parks and schools due to unsafe food.

Following from the results in the research model, with the characteristics of the food industry, it is a closed cycle and requires rhythmic coordination in the supply chain to ensure food hygiene and safety. Therefore, Institutional pressures also have a strong positive effect at the level of 0.269 (Hair et al., 2014) on Supply chain Integration at $1 \%$ significance level $\left(\mathrm{P} \_\right.$value $=$ 0.0000). Regulations on preservation and transportation to ensure food hygiene and safety make businesses in the food industry more closely linked. In the supply chain, the integration between the elements inside and outside the business is done more smoothly and efficiently.

On the other hand, when businesses participate in the global food supply chain, due to customer requirements, businesses are required to implement and ensure food hygiene and safety conditions, sometimes those activities to ensure food hygiene and safety are even higher than the provisions of the Law on Food Safety of Vietnam. Because American, Japanese and European customers have much higher requirements on food hygiene and safety. Therefore, integrated activities in the supply chain have a positive impact on Implementation of food safety practices with an impact factor of 0.193 at the $1 \%$ significance level $\left(P_{-}\right.$value $\left.=0.000\right)$.

In any country, businesses doing business are governed by the laws and regulations of the Government and the host State. Vietnam is no exception. Laws and regulations, collectively known as institutions, have a positive or negative impact on business orientations and strategies. In food production and business enterprises, laws, regulations, and institutions have a negative impact on the business strategy of food production and business enterprises with an impact coefficient of - 0.133 . at $1 \%$ significance level $\left(\mathrm{P}_{\text {_value }}=0.000\right)$. This means that for most businesses in the Vietnamese food industry, laws, regulations, and institutions negatively affect their business orientation. By retail, enterprises in the food industry in Vietnam, the export rate is not high, but mainly serves the domestic market. However, in the domestic market, people's income is not high, so to survive and develop in the market, businesses must compete on product prices. But to fully implement the regulations and laws of the state on food hygiene and safety, the price of the products sold will be very high and it will be difficult to compete to survive.

On the other hand, business orientations of enterprises have a very strong positive impact on Implementation of food safety practices with a very large impact factor of 0.447 at $1 \%$ significance level ( $\mathrm{P}$ _value $=0.000)$. When businesses have a longterm business orientation, for sustainable development goals, and building brand values, the business orientation will have a strong positive impact on the Implementation of food safety practices of businesses in the industry. Vietnamese food.

To evaluate the Implementation of food safety practices, the study also uses the Supply chain learning variable to assess the impact of enterprises' internal forces on their ability to react to market changes. Specifically, we look at the impact of Entrepreneurial orientation on Supply chain learning and Dynamic supply chain capabilities. The results show that the business orientations of businesses in the Vietnamese food industry have been interested in learning in the supply chain as shown from the research data as follows: Entrepreneurial orientation has a positive impact on supply. chain learning with an impact factor of 0.118 at $1 \%$ significance level $\left(P \_\right.$value $\left.=0.0000\right)$. Supply chain learning positively affects Dynamic supply chain capabilities with an impact factor of 0.160 at $1 \%$ significance level $\left(\mathrm{P}_{-}\right.$value $\left.=0.0000\right)$. Entrepreneurial orientation has a very strong impact - the strongest of the relationships in the research model - on Dynamic supply chain capabilities with an impact factor of 0.506 at $1 \%$ significance level $\left(P_{-}\right.$value $\left.=0.000\right)$. Indeed, the business orientation of the enterprise shows the ability of the enterprise to learn in all fields in general and in the supply chain. If an enterprise has an ethical business orientation, listens to stakeholders, especially in the supply chain, the value chain of the product, it will have the spirit to learn more. Especially when businesses are always innovative, creative, with a high spirit of learning and integration, the dynamic capacity of the supply chain will be very high. Because currently, businesses are always proactive in business activities in the supply chain, especially in the food industry, which depends a lot on uncertain factors of the business environment such as crop failure, epidemics, quality of input materials, output customer requirements. Therefore, the business orientation of the enterprise is extremely important and essential in ensuring the ability to learn in the supply chain and the capacity of the supply chain dynamism of the enterprise.

When the supply chain dynamic capacity and the ability to learn in the supply chain are high and proactive, it will have a positive impact on the Implementation of food safety practices of the enterprise. Consistent with resource-based theory and research by Abebe (2020); Aslam et al., (2020). Specifically, in this study, Dynamic supply chain capabilities have a statistically significant positive impact on Implementation of food safety practices with an impact factor of 0.275 at $1 \%$ significance level $\left(\mathrm{P}_{\text {_value }}=0.000\right)$; Supply chain learning has a statistically significant positive effect on Implementation of food safety practices with an impact factor of 0.286 at $1 \%$ significance level $\left(P_{-}\right.$value $\left.=0.000\right)$; 
Finally, from the results in the overall SEM model, it shows that Implementation of food safety practices has a statistically significant positive impact on Performance (Output) with an impact factor of 0.185 at $1 \%$ significance level $\left(\mathrm{P}_{-}\right.$value $=$ 0.007); This means that, although businesses in the Vietnamese food industry have not yet implemented good laws and regulations on food hygiene and safety. However, for businesses that have implemented regulations on food hygiene and safety, there is a positive impact on business performance for these businesses. This result is like the study of Abebe (2020) and Aslam et al. (2020).

Finally, the study examines the regulatory role of firm size and the proportion of exported products in the relationship between Institutional pressures and Implementation of food safety practices.

The regulatory role test model is as follows:

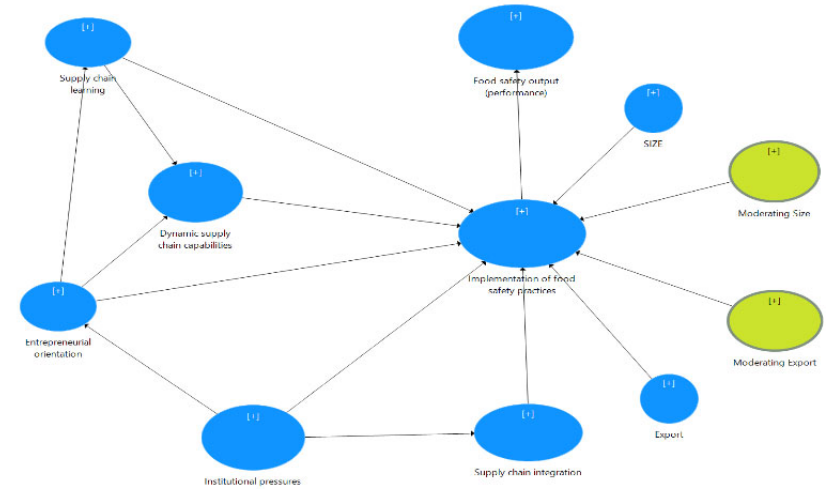

Fig. 3. Moderate model

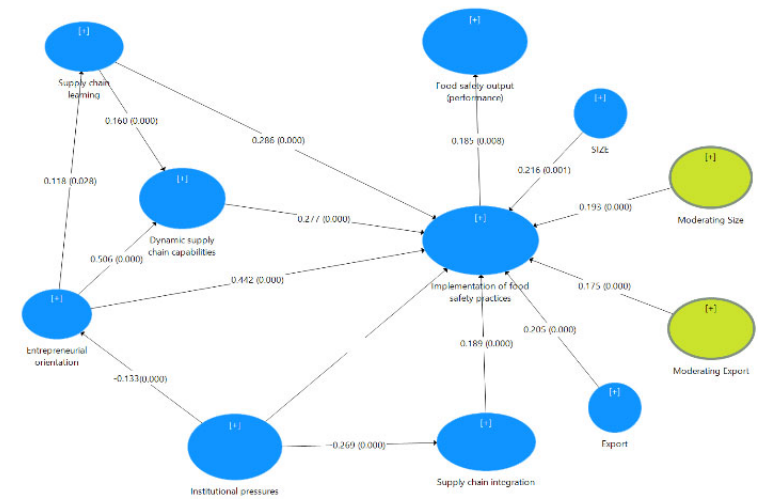

Fig. 4. Results of testing the regulatory role

From the bootstrap results in Fig. 3, it shows that Size and Export both have a statistically significant impact on Implementation of food safety practices with the respective impact coefficients 0.216 and 0.205 at $1 \%$ significance level with the corresponding $P_{-}$value. are 0.001 and 0.000 respectively. This means that the two control variables for firm size and the proportion of exported products qualify as moderators in the relationship between Institutional pressures and Implementation of food safety practices of firms in the food industry in Vietnam. We use techniques on Smart PLS 3.6 software to create two regulatory variables Size and Export as shown in Fig. 3. Then, we use Bootstrapping technique to test the research hypotheses. The results from Fig. 3 show that the two regulatory variables are statistically significant with the respective impact coefficients 0.193 and 0.175 , respectively, at the $1 \%$ significance level ( $P_{-}$value $=0.000$ ). To understand the impact mechanism of these two regulatory variables, the study conducts a more detailed analysis based on the impact coefficients as follows:

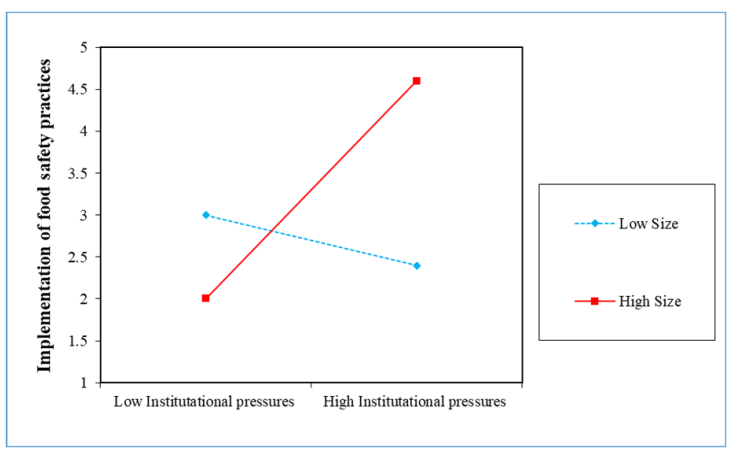

Fig. 5. Results of testing the regulatory role of Size

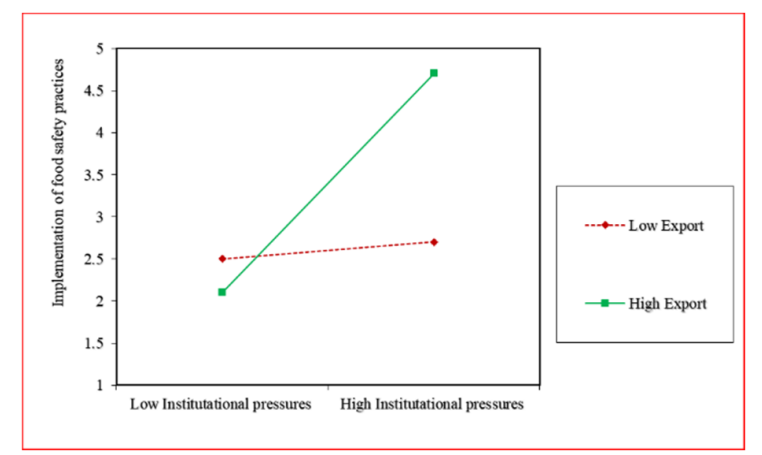

Fig. 6. Results of testing the regulatory role of the proportion of exported products

The results in Fig. 5 show that the larger the enterprises, the stronger the impact of state laws and regulations on the Implementation of food safety practices and vice versa, the more businesses in Vietnam's food industry the smaller the scale, the lower the Implementation of food safety practices. There are very few studies examining the regulatory role of Institutional pressures on Implementation of food safety practices, so this study's findings on the regulatory role of firm size are almost pioneering in the field. Given the context, Vietnam is a developing country, people's understanding of food hygiene and safety is not high due to the influence of wet rice culture many years ago. Therefore, Vietnamese consumers have not paid much attention to food traceability and whether the production process ensures food safety. Businesses in the Vietnamese food industry still compete mainly on price. With large enterprises, having the advantage of scale so that product costs are 
lower, they actively apply regulations and laws on food hygiene and safety to implement food safety practices in their businesses. However, the smaller the businesses, the more they do not have enough costs to cover the technological lines, the requirements for food preservation and processing. Therefore, small and micro enterprises tend to evade regulations and laws on food safety and hygiene. Unlike the size of enterprises, the proportion of exported products that regulate the influence of laws and regulations on food safety on the Implementation of food safety practices differ only in the magnitude of the impact. This means that $100 \%$ of businesses with a proportion of exported products are required to comply with regulations, regulations and laws on food hygiene and safety. Although studying enterprises with a larger proportion of exported products, the more proactive the Implementation of food safety practices is. In particular, the straight line shows the relationship between Institutional pressures and Implementation of food safety practices in enterprises with a larger export ratio, the steeper and higher, so the impact will be stronger. However, in firms with a lower proportion of exported products, the straight line representing the relationship has a lower slope, so the magnitude of the effect is weaker. The summary of the research hypotheses is as follows:

Table 6

Path Coefficients: The summary of some basic statistics

\begin{tabular}{|c|c|c|c|c|c|}
\hline & $\begin{array}{c}\text { Original } \\
\text { Sample }(\mathrm{O}) \\
\end{array}$ & $\begin{array}{c}\text { Sample } \\
\text { Mean (M) }\end{array}$ & $\begin{array}{l}\text { Standard Deviation } \\
\text { (STDEV) }\end{array}$ & $\begin{array}{l}\text { T Statistics } \\
(|\mathrm{O} / \mathrm{STDEV}|)\end{array}$ & P Values \\
\hline $\begin{array}{l}\text { Dynamic supply chain capabilities } \rightarrow \text { Implementation of } \\
\text { food safety practices }\end{array}$ & 0.277 & 0.276 & 0.058 & 4.785 & 0.000 \\
\hline $\begin{array}{l}\text { Entrepreneurial orientation } \rightarrow \text { Dynamic supply chain } \\
\text { capabilities }\end{array}$ & 0.506 & 0.508 & 0.042 & 12.115 & 0.000 \\
\hline $\begin{array}{l}\text { Entrepreneurial orientation } \rightarrow \text { Implementation of food } \\
\text { safety practices }\end{array}$ & 0.442 & 0.446 & 0.054 & 8.127 & 0.000 \\
\hline Entrepreneurial orientation $\rightarrow$ Supply chain learning & 0.118 & 0.126 & 0.053 & 2.206 & 0.028 \\
\hline Export $\rightarrow$ Implementation of food safety practices & -0.004 & -0.001 & 0.039 & 4.673 & 0.000 \\
\hline Implementation of food safety practices $\rightarrow$ Performance & 0.185 & 0.191 & 0.069 & 2.657 & 0.008 \\
\hline Institutional pressures $\rightarrow$ Entrepreneurial orientation & -0.133 & -0.138 & 0.061 & 2.174 & 0.030 \\
\hline $\begin{array}{l}\text { Institutional pressures } \rightarrow \text { Implementation of food safety } \\
\text { practices }\end{array}$ & 0.043 & 0.042 & 0.046 & 12.135 & 0.000 \\
\hline Institutional pressures $\rightarrow$ Supply chain integration & 0.269 & 0.275 & 0.058 & 4.677 & 0.000 \\
\hline $\begin{array}{l}\text { Moderating Export } \rightarrow \text { Implementation of food safety } \\
\text { practices }\end{array}$ & 0.043 & 0.043 & 0.041 & 8.243 & 0.000 \\
\hline $\begin{array}{l}\text { Moderating Size } \rightarrow \text { Implementation of food safety } \\
\text { practices }\end{array}$ & 0.058 & 0.056 & 0.047 & 4.530 & 0.000 \\
\hline SIZE $\rightarrow$ Implementation of food safety practices & -0.045 & -0.044 & 0.040 & 3.872 & 0.000 \\
\hline $\begin{array}{l}\text { Supply chain integration } \rightarrow \text { Implementation of food } \\
\text { safety practices }\end{array}$ & -0.126 & -0.126 & 0.044 & 2.851 & 0.004 \\
\hline $\begin{array}{l}\text { Supply chain learning } \rightarrow \text { Dynamic supply chain } \\
\text { capabilities }\end{array}$ & 0.160 & 0.162 & 0.042 & 3.862 & 0.000 \\
\hline $\begin{array}{l}\text { Supply chain learning } \rightarrow \text { Implementation of food safety } \\
\text { practices }\end{array}$ & 0.057 & 0.055 & 0.042 & 4.231 & 0.000 \\
\hline
\end{tabular}

\section{Conclusion}

The world food industry is constantly evolving, as new advances in technology with the fourth industrial revolution, green production, cost savings from participating in the product supply chain, changing consumer tastes and increasing demand for healthy food is the development trend of the food industry in the future. Participating in a product supply chain has brought the opportunity to reduce costs for food businesses by rationalizing and optimizing their operations. From product design, to production, processing, sales, and customer satisfaction are operated and managed by a single process and system. This gives businesses the opportunity to understand customers and always can innovate to extend the life cycle of food products. The demand for food in the world is increasingly diversified due to the growth of the global population and the tendency of many customers to travel. More than ever, customers have more opportunities to use different foods and flavors. Food businesses also need to make sure to continuously evaluate the quality of their food because customers are always looking for new and safe products. However, the increased demand for new products means that the product's life cycle will be shortened. Food is an important sector of the economy, with stable growth over the past time and a significant contribution to GDP growth in the country. With an agricultural economy like Vietnam, food is a spearhead industry, contributing to changing and increasing the output value of agricultural products, helping to create jobs and develop the local economy.

Trends in investment in the production of clean products: As income increases, consumers are willing to pay a higher level of spending on healthy and environmentally friendly food products. Vietnam is one of the leading countries in exporting agricultural products, but the lines of processed products, especially clean products that are processed safely and delicately, have not been effectively exploited. The main reason is due to the difference in technology level, equipment and human 
resources. This is a weakness of domestic enterprises when competing with foreign enterprises. The handshake with foreign enterprises through the form of strategic cooperation is expected to change the production method of domestic enterprises today. Vietnamese consumers are increasingly interested in food safety and hygiene. Increasing incomes also increase the demand for convenient packaged foods, as well as higher quality, healthy, hygienic, safe and food products. As a result, demand for safe packaged foods and processed ingredients is expected to grow.

To achieve the goals of green growth and sustainable development as well as ensure food hygiene and safety, the role of law is very important. The law aims at ensuring food safety through legal norms and regulations on organizational structure for state agencies in this field. That will be the legal basis to carry out food safety inspection and supervision throughout the country. Firstly: Food safety legislation is the basis for functional agencies responsible for ensuring food safety throughout the country to well perform their responsibilities from central to local levels. Secondly: The law on food safety is a "template" that creates a premise to regulate behaviors and social relations in a unified way to ensure food safety. It is also a basis for letting people know what they can do, what they can't do, and how to ensure food safety during production and business. Thirdly: Food safety legislation is the basis for inspection, supervision, management and handling if there is a violation in the field of food safety of the enterprise. From there, it will contribute to reducing restrictions as well as preventing and repelling all violations that cause food insecurity. Fourthly: The food safety law is the legal representative of all people when exercising their mastery, which is: inspecting and monitoring illegal acts, causing food insecurity.

\section{References}

Abebe, G. K., Bahn, R. A., Chalak, A., \& Yehya, A. A. K. (2020). Drivers for the implementation of market-based food safety management systems: Evidence from Lebanon. Food Science \& Nutrition, 8(2), 1082-1092.

Akkerman, R., Farahani, P., \& Grunow, M. (2010). Quality, safety and sustainability in food distribution: a review of quantitative operations management approaches and challenges. OR Spectrum, 32(4), 863-904.

Aslam, U., Muqadas, F., Imran, M.K., \& Saboor, A. (2018). Emerging organizational parameters and their roles in implementation of organizational change. Journal of Organizational Change Management, 31, 1084-1104.

Aslam, U., Rehman, M., Imran, M. K., \& Muqadas, F. (2016). The impact of teacher qualifications and experience on student satisfaction: a mediating and moderating research model. Pakistan Journal of Commerce and Social Sciences (PJCSS), 10(3), 505-524.

Aslam, U., Muqadas, F., Imran, M.K., \& Ubaid-ur-Rahman (2018). Exploring the sources and role of knowledge sharing to overcome the challenges of organizational change implementation. International Journal of Organizational Analysis, 26, $567-581$.

Aslam, H.B., Blome, C., Roscoe, S., \& Azhar, T.M. (2018). Dynamic supply chain capabilities: how market sensing, supply chain agility and adaptability affect supply chain ambidexterity. International Journal of Operations \& Production Management, 38, 2266-2285.

Bhakoo, V., \& Choi, T. (2013). The iron cage exposed: Institutional pressures and heterogeneity across the healthcare supply chain. Journal of Operations Management, 31(6), 432-449.

Blome, S., Gabriel, C., Schmeiser, S., Meyer, D., Meindl-Böhmer, A., Koenen, F., \& Beer, M. (2014). Efficacy of marker vaccine candidate CP7_E2alf against challenge with classical swine fever virus isolates of different genotypes. Veterinary Microbiology, 169(1-2), 8-17.

Blome, S., Grotha, I., Moennig, V., \& Greiser-Wilke, I. (2010). Classical swine fever virus in South-Eastern EuropeRetrospective analysis of the disease situation and molecular epidemiology. Veterinary Microbiology, 146(3-4), 276-284.

Blome, C., Schoenherr, T., \& Kaesser, M. (2013). Ambidextrous governance in supply chains: The impact on innovation and cost performance. Journal of Supply Chain Management, 49(4), 59-80.

Braunscheidel, M. J., \& Suresh, N. C. (2009). The organizational antecedents of a firm's supply chain agility for risk mitigation and response. Journal of Operations Management, 27(2), 119-140.

Bharadwaj, N., \& Dong, Y. (2014). Toward further understanding the market-sensing capability-value creation relationship. Journal of Product Innovation Management, 31(4), 799-813.

Jones, A. B., \& Knoppen, D. (2018). The role of strategic purchasing in dynamic capability development and deployment: A contingency perspective. International Journal of Operations \& Production Management, 38(2), 446-473.

Beske, P., Land, A., \& Seuring, S. (2014). Sustainable supply chain management practices and dynamic capabilities in the food industry: A critical analysis of the literature. International Journal of Production Economics, 152, 131-143.

Beske, P., \& Seuring, S. (2014). Putting sustainability into supply chain management. Supply Chain Management, 19, 322331.

Beske, P. (2012). Dynamic capabilities and sustainable supply chain management. International Journal of Physical Distribution \& Logistics Management, 42, 372-387.

Browning, T. R., \& Sanders, N. R. (2012). Can innovation be lean?. California Management Review, 54(4), 5-19.

Chen, I. J., \& Paulraj, A. (2004). Understanding supply chain management: critical research and a theoretical framework. International Journal of Production Research, 42(1), 131-163.

Childerhouse, P., \& Towill, D. R. (2006). Enabling seamless market-orientated supply chains. International Journal of Logistics Systems and Management, 2(4), 357-370.

Christopher, M. (2016). Logistics \& supply chain management. Pearson Uk. 
Christopher, M., \& Towill, D. R. (2000). Supply chain migration from lean and functional to agile and customised. Supply Chain Management: An International Journal, 5(4), 206-213.

Christopher, M., \& Towill, D. R. (2001). An integrated model for the design of agile enterprise. International Journal of Physical Distribution and Logistics Management, 31(4), 235-246.

Choi, J. H., Lim, H. Y., Nam, D. K., Kim, H. S., Cho, D. Y., Yi, J. W., ... \& Kim, K. B. (2001). Expression of thymidylate synthase in gastric cancer patients treated with 5-fluorouracil and doxorubicin-based adjuvant chemotherapy after curative resection. British Journal of Cancer, 84(2), 186-192.

Cousins, P. D., Lawson, B., Petersen, K. J., \& Handfield, R. B. (2011). Breakthrough scanning, supplier knowledge exchange, and new product development performance. Journal of Product Innovation Management, 28(6), 930-942.

Covin, J. G., \& Slevin, D. P. (1988). The influence of organization structure on the utility of an entrepreneurial top management style. Journal of Management Studies, 25(3), 217-234.

Covin, J. G., \& Slevin, D. P. (1989). Strategic management of small firms in hostile and benign environments. Strategic management journal, 10(1), 75-87.

Covin, J. G., Green, K. M., \& Slevin, D. P. (2006). Strategic process effects on the entrepreneurial orientation-sales growth rate relationship. Entrepreneurship Theory and Practice, 30(1), 57-81.

Cousin, H., Abbruzzese, G., Kerdavid, E., Gaultier, A., \& Alfandari, D. (2011). Translocation of the cytoplasmic domain of ADAM13 to the nucleus is essential for Calpain8-a expression and cranial neural crest cell migration. Developmental cell, 20(2), 256-263.

Davidson, R., \& Flachaire, E. (2008). The wild bootstrap, tamed at last. Journal of Econometrics, 146(1), $162-169$.

Davison, A. C., \& Hinkley, D. V. (1997). Bootstrap methods and their application (No. 1). Cambridge university press.

DiMaggio, P. J., \& Powell, W. W. (1983). The iron cage revisited: Institutional isomorphism and collective rationality in organizational fields. American Sociological Review, 147-160.

Dubey, R. (2015). An insight on soft TQM practices and their impact on cement manufacturing firm's performance: Does size of the cement manufacturing firm matter? Business Process Management Journal, 21, 2-24.

Dubey, R., Gunasekaran, A., \& Ali, S. S. (2015). Exploring the relationship between leadership, operational practices, institutional pressures and environmental performance: A framework for green supply chain. International Journal of Production Economics, 160, 120-132.

Tripti, R., \& Singh, A. (2015). The mediating effect of human resource on successful total quality management implementation. Benchmarking: An International Journal, 22(7), 1463-1480.

Dubey, R., Gunasekaran, A., Childe, S. J., Papadopoulos, T., Hazen, B. T., \& Roubaud, D. (2018). Examining top management commitment to TQM diffusion using institutional and upper echelon theories. International Journal of Production Research, 56(8), 2988-3006.

Day, G. S. (2014). An outside-in approach to resource-based theories. Journal of the Academy of Marketing Science, 42(1), 27-28.

Dess, G. G., \& Lumpkin, G. T. (2005). The role of entrepreneurial orientation in stimulating effective corporate entrepreneurship. Academy of Management Perspectives, 19(1), 147-156.

Kurth, L., \& Glasbergen, P. (2017). Serving a heterogeneous Muslim identity? Private governance arrangements of halal food in the Netherlands. Agriculture and Human Values, 34(1), 103-118.

Kittipanya-Ngam, P., \& Tan, K. H. (2020). A framework for food supply chain digitalization: lessons from Thailand. Production Planning \& Control, 31(2-3), 158-172.

Ketchen Jr, D. J., \& Giunipero, L. C. (2004). The intersection of strategic management and supply chain management. Industrial Marketing Management, 33(1), 51-56.

Ketchen, D.J., \& Hult, G.T. (2007). Bridging organization theory and supply chain management: The case of best value supply chains. Journal of Operations Management, 25, 573-580.

Jacobs, M. A., Yu, W., \& Chavez, R. (2016). The effect of internal communication and employee satisfaction on supply chain integration. International Journal of Production Economics, 171, 60-70.

Ju, J., Kim, M. S., \& Ahn, J. H. (2016). Prototyping business models for IoT service. Procedia Computer Science, 91 , 882890.

Gupta, R. P., Rai, A., \& Gupta, N. (2014). A study of anatomical variations in foramen transversarium and its clinical importance. International Journal of Contemporary Surgery, 2(1), 147.

Gligor, D.M., \& Holcomb, M.C. (2012). Understanding the role of logistics capabilities in achieving supply chain agility: a systematic literature review. Supply Chain Management, 17, 438-453.

Eckstein, D., Goellner, M., Blome, C., \& Henke, M. (2015). The performance impact of supply chain agility and supply chain adaptability: the moderating effect of product complexity. International Journal of Production Research, 53(10), 30283046.

Fornell, C., \& Larcker, D.F. (1981). Structural Equation Models with Unobservable Variables and Measurement Error: Algebra and Statistics. Journal of Marketing Research, 18, 382-388.

Fortis, Z., Maon, F., Frooman, J., \& Reiner, G. (2018). Unknown knowns and known unknowns: Framing the role of organizational learning in corporate social responsibility development. International Journal of Management Reviews, 20(2), 277-300. 
Prajogo, D.I., Oke, A., \& Olhager, J. (2016). Supply chain processes: Linking supply logistics integration, supply performance, lean processes, and competitive performance. International Journal of Operations \& Production Management, 36, 220-238.

Prajogo, D., \& Olhager, J. (2012). Supply chain integration and performance: The effects of long-term relationships, information technology and sharing, and logistics integration. International Journal of Production Economics, 135(1), 514-522.

Powell, W. W., Koput, K. W., \& Smith-Doerr, L. (1996). Interorganizational collaboration and the locus of innovation: Networks of learning in biotechnology. Administrative Science Quarterly, 116-145.

Hair, J. F., Ringle, C. M., \& Sarstedt, M. (2011). PLSSEM: Indeed a Silver Bullet. Journal of Marketing Theory and Practice, 19(2), 139-152

Hair Jr, J. F., Hult, G. T. M., Ringle, C. M., \& Sarstedt, M. (2021). A primer on partial least squares structural equation modeling (PLS-SEM). Sage publications.

Henseler, J., Dijkstra, T.K., Sarstedt, M., Ringle, C.M., Diamantopoulos, A., Straub, D.W., Ketchen, D.J., Hair, J.F., Hult, G.T., \& Calantone, R. (2014). Common Beliefs and Reality About Partial Least Squares: Comments on Rönkkö \& Evermann (2013).

Hair Jr, J. F., Hult, G. T. M., Ringle, C. M., \& Sarstedt, M. (2021). A primer on partial least squares structural equation modeling (PLS-SEM). Sage publications.

Hattersley, L., Isaacs, B., \& Burch, D. (2013). Supermarket power, own-labels, and manufacturer counterstrategies: international relations of cooperation and competition in the fruit canning industry. Agriculture and Human Values, 30(2), 225-233.

Henseler, J., Ringle, C. M., \& Sarstedt, M. (2015). A new criterion for assessing discriminant validity in variance-based structural equation modeling. Journal of the Academy of Marketing Science, 43(1), 115-135.

Henseler, J., Ringle, C. M., \& Sinkovics, R. R. (2009). The use of partial least squares path modeling in international marketing. In New challenges to international marketing. Emerald Group Publishing Limited.

Hong, Q., Liu, C., Chan, K. L., Hu, Q., Xie, Z., Liu, H., ... \& Liu, J. (2018). Ship-based MAX-DOAS measurements of tropospheric NO 2, SO 2, and HCHO distribution along the Yangtze River. Atmospheric Chemistry and Physics, 18(8), 5931-5951.

Hakala, H. (2011). Strategic orientations in management literature: Three approaches to understanding the interaction between market, technology, entrepreneurial and learning orientations. International Journal of Management Reviews, 13(2), 199-217.

John, C. H. S., Cannon, A. R., \& Pouder, R. W. (2001). Change drivers in the new millennium: implications for manufacturing strategy research. Journal of Operations Management, 19(2), 143-160.

Jantunen, A., Puumalainen, K., Saarenketo, S., \& Kyläheiko, K. (2005). Entrepreneurial orientation, dynamic capabilities and international performance. Journal of International Entrepreneurship, 3(3), 223-243.

Jacobs, M. A., Yu, W., \& Chavez, R. (2016). The effect of internal communication and employee satisfaction on supply chain integration. International Journal of Production Economics, 171, 60-70.

Luning, P. A., Marcelis, W. J., Rovira, J., Van Boekel, M. A. J. S., Uyttendaele, M., \& Jacxsens, L. (2011). A tool to diagnose context riskiness in view of food safety activities and microbiological safety output. Trends in Food Science \& Technology, 22, S67-S79.

Luning, P. A., Kirezieva, K., Hagelaar, G. J. L. F., Rovira, J., Uyttendaele, M., \& Jacxsens, L. (2015). Performance assessment of food safety management systems in animal-based food companies in view of their context characteristics: A European study. Food Control, 49, 11-22.

Lee, H. L. (2002). Aligning supply chain strategies with product uncertainties. California Management Review, 44(3), 105119.

Lee, H. L. (2004). The triple-A supply chain. Harvard Business Review, 82(10), 102-113.

Lee, S.M., \& Rha, J.S. (2016). Ambidextrous supply chain as a dynamic capability: building a resilient supply chain. Management Decision, 54, 2-23.

March, J. G., \& Olsen, J. P. (1983). The new institutionalism: Organizational factors in political life. American Political Science Review, 78(3), 734-749.

Ménard, C., \& Valceschini, E. (2005). New institutions for governing the agri-food industry. European Review of Agricultural Economics, 32(3), 421-440.

Morgan, D. G., Crossley, M., Kirk, A., D’Arcy, C., Stewart, N., Biem, J., ... \& McBain, L. (2009). Improving access to dementia care: development and evaluation of a rural and remote memory clinic. Aging and Mental Health, 13(1), 17-30.

Morgan, D. G., Kosteniuk, J. G., Stewart, N. J., O’Connell, M. E., Kirk, A., Crossley, M., ... \& Innes, A. (2015). Availability and primary health care orientation of dementia-related services in rural Saskatchewan, Canada. Home Health Care Services Quarterly, 34(3-4), 137-158.

Miller, D. (1983). The correlates of entrepreneurship in three types of firms. Management Science, 29(7), $770-791$.

Ngai, E. W., Law, C. C., \& Wat, F. K. (2008). Examining the critical success factors in the adoption of enterprise resource planning. Computers in Industry, 59(6), 548-564.

Stranieri, S., Orsi, L., \& Banterle, A. (2017). Traceability and risks: an extended transaction cost perspective. Supply Chain Management, 22, 145-159. 
Swafford, P. M., Ghosh, S., \& Murthy, N. (2006). The antecedents of supply chain agility of a firm: scale development and model testing. Journal of Operations Management, 24(2), 170-188.

Swafford, P. M., Ghosh, S., \& Murthy, N. (2008). Achieving supply chain agility through IT integration and flexibility. International Journal of Production Economics, 116(2), 288-297.

Sahi, G., Gupta, M.C., \& Cheng, T.C. (2020). The effects of strategic orientation on operational ambidexterity: A study of indian SMEs in the industry 4.0 era. International Journal of Production Economics, 220, 107395.

Stam, W., \& Elfring, T. (2008). Entrepreneurial orientation and new venture performance: The moderating role of intra-and extraindustry social capital. Academy of Management Journal, 51(1), 97-111.

Trienekens, J., \& Wognum, N. (2013). Requirements of supply chain management in differentiating European pork chains. Meat Science, 95(3), 719-726.

Trienekens, J. H., Wognum, P. M., Beulens, A. J., \& van der Vorst, J. G. (2012). Transparency in complex dynamic food supply chains. Advanced Engineering Informatics, 26(1), 55-65.

Trienekens, J., \& Zuurbier, P. (2008). Quality and safety standards in the food industry, developments and challenges. International Journal of Production Economics, 113(1), 107-122.

Tan, K.H., Ali, M.H., Makhbul, Z.K., \& Ismail, A. (2017). The impact of external integration on halal food integrity. Supply Chain Management, 22, 186-199.

Tse, Y.K., Zhang, M., Akhtar, P., \& MacBryde, J. (2016). Embracing supply chain agility: an investigation in the electronics industry. Supply Chain Management, 21, 140-156.

Teece, D. J. (2007). Explicating dynamic capabilities: the nature and microfoundations of (sustainable) enterprise performance. Strategic Management Journal, 28(13), 1319-1350.

Teece, D. J. (2010). Business models, business strategy and innovation. Long Range Planning, 43(2-3), 172-194.

Teece, D. J. (2014). The foundations of enterprise performance: Dynamic and ordinary capabilities in an (economic) theory of firms. Academy of Management Perspectives, 28(4), 328-352.

Teece, D. J. (2018). Business models and dynamic capabilities. Long Range Planning, 51(1), 40-49.

Teece, D. J., Pisano, G., \& Shuen, A. (1997). Dynamic capabilities and strategic management. Strategic Management Journal, 18(7), 509-533.

Teece, D., Peteraf, M., \& Leih, S. (2016). Dynamic capabilities and organizational agility: Risk, uncertainty, and strategy in the innovation economy. California Management Review, 58(4), 13-35.

Vanpoucke, E., Vereecke, A., \& Muylle, S. (2017). Leveraging the impact of supply chain integration through information technology. International Journal of Operations \& Production Management, 37, 510-530.

Wever, M., Wognum, P. M., Trienekens, J. H., \& Omta, S. W. F. (2012). Supply chain-wide consequences of transaction risks and their contractual solutions: Towards an extended transaction cost economics framework. Journal of Supply Chain Management, 48(1), 73-91.

Williamson, O. E. (1991). Comparative economic organization: The analysis of discrete structural alternatives. Administrative Science Quarterly, 36(2), 269-296.

Whitten, G.D., Green, K.W., \& Zelbst, P.J. (2012). Triple-A supply chain performance. International Journal of Operations \& Production Management, 32, 28-48.

Wu, T., Daniel, E.M., Hinton, M., \& Quintas, P. (2013). Isomorphic mechanisms in manufacturing supply chains: a comparison of indigenous Chinese firms and foreign-owned MNCs. Supply Chain Management, 18, 161-177.

Wiklund, J., \& Shepherd, D. (2005). Entrepreneurial orientation and small business performance: a configurational approach. Journal of Business Venturing, 20(1), 71-91.

Zhang, X., Donk, D.P., \& Vaart, T.V. (2009). The different impact of inter-organizational and intra-organizational ICT on supply chain performance. International Journal of Operations \& Production Management, 36, 803-824.

Zhang, X., \& Aramyan, L.H. (2009). A conceptual framework for supply chain governance: An application to agri-food chains in China. China Agricultural Economic Review, 1, 136-154.

Zhu, Q., \& Sarkis, J. (2007). The moderating effects of institutional pressures on emergent green supply chain practices and performance. International Journal of Production Research, 45(18-19), 4333-4355.

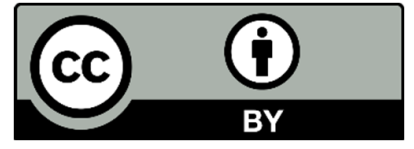

(C) 2022 by the authors; licensee Growing Science, Canada. This is an open access article distributed under the terms and conditions of the Creative Commons Attribution (CCBY) license (http://creativecommons.org/licenses/by/4.0/). 